\title{
Cattle Diets in a Ponderosa Pine Forest in the North- ern Black Hills
}

\author{
DANIEL W. URESK AND WAYNE W. PAINTNER
}

\begin{abstract}
A cattle diet study was conducted in the northern Black Hills of South Dakota and Wyoming. Forty-eight plants were identified in cattle fecal material. Grasses in the feces averaged 54\%, forbs $17 \%$, and shrubs-trees $28 \%$ over the grazing season. Sedges (Carex spp.) and wheatgrass (Agropyron spp.) were the most abundant plants found in the feces throughout the season. Bur oak (Quercus macrocarpa), ponderosa pine (Pinus ponderosa), and Oregon grape (Berberis repens) were common in the diet. Shrubs and trees made up 37\% of the diet in September. Similarities and rank order correlations of diets with available forage were low in August, indicating that cattle were selectively grazing.
\end{abstract}

The Black Hills of western South Dakota and eastern Wyoming support forest cover with an associated understory that is an important food source to herbivores (Pase and Hurd 1957, Pase 1958, Severson and Boldt 1977). Cattle graze the area during the summer. However, data on cattle food habits are limited, and information is needed for effective long-term management, particularly forage allocation for cattle grazing.

\section{Study Area and Methods}

The Black Hills are dominated by ponderosa pine (Pinus ponderosa). In addition, white spruce (Picea glauca), paper birch (Betula papyrifera), quaking aspen (Populus tremuloides), and bur oak (Quercus macrocarpa) are found in varying amounts (Boldt et al. 1983). Mean annual precipitation for the Black Hills is $76 \mathrm{~cm}$ with most of the precipitation falling from April through July.

I he study area was the northern Black Hills ranging from Spearfish, S. Dak., west to Beulah, Wyo. Vegetation, including trees of the study area, was heterogeneous. Trees in the forest were not low growing except for bur oak, which in several areas was shrub-like. Understory shrub species included Oregon grape (Berberis repens), common chokecherry (Prunus virginiana), Saskatoon serviceberry (Amelanchier alnifolia), snowberry (Symphoricarpos albus), and bur oak (Thilenius 1972). Common grass species were roughleaf ricegrass (Oryzopsis asperifolia), timber oatgrass (Danthonia intermedia), and Kentucky bluegrass (Poa pratensis). Understory forage production and composition has been reported by Pase and Hurd (1957), Pase (1958), and Severson and Boldt (1977).

Ten representative sampling areas were selected within larger range sites in the northern Black Hills during 1978, which included drainages of Dougout Gulch (1,377 ha), Sand Creek (2,137 ha), Big Hill (2,714 ha), Knight Spring (932 ha), E.F. Higgins (1,134 ha), Boundary Spring (1,418 ha), and Thompson Spring (729 ha). These areas made up the potential range for the cattle; however, the total area was not fully used by cattle because of topography and lack of a vailable water. It is estimated that $30 \%$ of the pasture area receives more than $60 \%$ of the cattle grazing (Senft et al. 1983). Daily movements of cattle on wooded areas range from $3.2 \mathrm{~km}$ to $8.7 \mathrm{~km}$ (Bjugstad and Dalrymple 1968).

Cattle feces were collected at all 10 areas weekly, from June

\footnotetext{
Authors are research biologist. Rocky Mountain Forest and Range Experiment Station Research Work Unit in Rapid City, S. Dak. 57701, in cooperation with the South Dakota School of Mines. (Station headquarters is in Fort Collins, in cooperation with Colorado State University.); and supervisory resource forester, USDA Forest Service, Sula Ranger District, Bitterroot National Forest, Sula, Mont. 59871. Manuscript accepted April 15, 1985.
}

through September ( 14 periods). Five fresh fecal samples were collected by walking transects at random, based on direction of the watch dials at time of sampling from north (12:00), on each area. Each sample was air dried, then was ground through a Wiley mill fitted with a 1-mm screen, and was thoroughly mixed. One slide was made of each fecal sample. Twenty fields were examined for each slide at $100 \mathrm{X}$, for a total of 100 fields per site per week. All procedures followed Sparks and Malechek (1968) and Rogers and Uresk (1974). A total of 700 fecal samples were analyzed by the microscopic technique.

Understory vegetation $(<2 \mathrm{~m}$ tall) at each area was measured for canopy cover during August, near peak plant production, along two 30-m line transects. Transects were established in areas of high cattle concentration on each area. All transects were established in each of the 10 areas which represented the major vegetation used by cattle. Canopy cover by plant species was estimated by visual examination of $30\left(2 \times 5 \mathrm{dm}, 0.1 \mathrm{~m}^{2}\right)$ quadrats, systematically spaced at $1-\mathrm{m}$ intervals along cach line transect (Daubenmire 1959). Canopy cover values were summarized by transect and site. Canopy cover values are used as a suitable index of herbage production for most plant species (Payne 1974) as related to cattle diets. Plant names follow Nickerson et al. (1976).

Dietary and canopy cover values were averaged monthly by site for statistical analyses. Kulczynski's Similarity Index (Oosting 1956) and Spearman's rank order correlation $\left(r_{s}\right)$ (Siegel 1956) compared August cattle diets and plant canopy cover to determine degree of association. A paired T-test was used for comparisons between species in diets with canopy cover. Changes in individual plant species and categories of monthly diets were analyzed using one-factor analysis of variance (Nie et al. 1975). The F-protected LSD was used to perform pairwise comparisons among months (Carmer and Swanson 1973). When variances were homogeneous according to the Bartlett-Box $F$ test, pooled variance estimates were used for multiple variances. When the $\arcsin [\mathrm{Sqrt}(\mathrm{Y})]$ transformation did not correct for heterogeneous variances, Dunnett's T3 method for nonhomogeneous variances was applied (Dunnett 1980).

\section{Results}

Botanical composition of the cattle diets averaged over the grazing season showed that grasses $(54 \%)$ were the major food items, followed by shrubs-trees $(28 \%)$, and forbs $(17 \%)$. Grasses were relatively consistent in the monthly cattle diets, ranging from $51 \%$ to $57 \%$ (Table 1). Sedges (Carex spp.), wheatgrass (Agropyron spp.), and timber oatgrass were the most abundant plants grazed by cattle throughout the grazing season. Needle grasses (Stipa spp.) were greatest in the cattle diets in September. Shrubs and trees were a greater portion of the cattle diets as the grazing season progressed, increasing from $19 \%$ in June to $37 \%$ by September; but, these differences were not significant $(P<0.10)$. Bur oak was found in the cattle diets throughout the season, averaging $12 \%$. Ponderosa pine and Oregon grape were greater in the diets later in the season. Forbs in the diets were greatest in June $(29 \%)$; however, by September, forbs made up $6 \%$ of the diet. White clover (Trifolium repens) was the most abundant forb grazed in the early part of the grazing season (14\%). However, it declined in impor- 
Table 1. Average monthly diets $(\% \pm \mathrm{SE})$ of cattle by plant species in the northern Black Hills.

\begin{tabular}{|c|c|c|c|c|}
\hline Category & June & July & August & September \\
\hline $\begin{array}{l}\text { Grasses and grasslikes } \\
\text { Agropyron spp. } \\
\text { Agrostis spp. } \\
\text { Andropogon gerardii } \\
\text { Bromus inermis } \\
\text { Carex spp. } \\
\text { Danthonia intermedia } \\
\text { Muhlenbergia racemosa } \\
\text { Oryzopsis spp. } \\
\text { Poa pratensis } \\
\text { Sorgastrum nutans } \\
\text { Stipa spp. } \\
\text { Equisetium spp. } \\
\text { Other spp. }{ }^{2}\end{array}$ & $\begin{array}{c}14.7 \pm 4.1 \\
0.9 \pm 0.4 \\
1.3 \pm 1.3 \\
3.2 \pm 0.8^{\mathrm{ab}} \\
10.8 \pm 3.0 \\
6.9 \pm 1.6 \\
3.2 \pm 0.9 \\
1.2 \pm 0.5^{\mathrm{a}} \\
3.3 \pm 1.4 \\
0.0 \\
3.4 \pm 1.6^{\mathrm{a}} \\
0.0 \\
2.1 \\
\end{array}$ & $\begin{array}{l}5.3 \pm 1.3 \\
3.2 \pm 0.9 \\
7.7 \pm 2.8 \\
3.7 \pm 0.8^{\mathrm{a}} \\
9.3 \pm 1.5 \\
7.9 \pm 1.6 \\
4.6 \pm 1.2 \\
2.7 \pm 0.9^{\mathrm{b}} \\
4.3 \pm 1.2 \\
2.2 \pm 1.1 \\
3.4 \pm 0.7^{\mathrm{a}} \\
0.7 \pm 0.4 \\
1.8\end{array}$ & $\begin{array}{l}6.6 \pm 1.6 \\
1.8 \pm 0.7 \\
4.6 \pm 2.5 \\
4.6 \pm 0.9^{n} \\
8.2 \pm 1.1 \\
9.0 \pm 1.9 \\
4.4 \pm 1.8 \\
0.6 \pm 0.2^{n} \\
5.0 \pm 1.1 \\
0.2 \pm 0.1 \\
7.1 \pm 1.5^{n} \\
0.0 \\
0.7 \\
\end{array}$ & $\begin{array}{r}8.6 \pm 1.2 \\
2.3 \pm 0.5 \\
0.9 \pm 0.5 \\
1.7 \pm 0.5^{b} \\
11.3 \pm 2.2 \\
6.6 \pm 0.9 \\
1.7 \pm 0.8 \\
0.5 \pm 0.2^{\mathrm{a}} \\
3.2 \pm 0.9 \\
0.2 \pm 0.2 \\
15.9 \pm 1.4^{\mathrm{b}} \\
1.4 \pm 0.2 \\
2.9 \\
\end{array}$ \\
\hline Total & $51.0 \pm 7.2$ & $56.8 \pm 5.1$ & $52.8 \pm 5.9$ & $56.2 \pm 3.3$ \\
\hline $\begin{array}{l}\text { Forbs } \\
\text { Composite spp. } \\
\text { Erigeron spp. } \\
\text { Potentilla spp. } \\
\text { Trifolium repens } \\
\text { Verbascus thapsus } \\
\text { Vicia spp. } \\
\text { Other spp. } \\
\text { Unknowns }\end{array}$ & $\begin{array}{l}3.9 \pm 1.2^{\mathrm{a}} \\
1.6 \pm 0.7 \\
1.1 \pm 0.4 \\
14.0 \pm 3.9^{\mathrm{a}} \\
0.8 \pm 0.3 \\
2.0 \pm 0.9^{\mathrm{a}} \\
2.6 \\
2.9\end{array}$ & $\begin{array}{l}1.8 \pm 0.5^{b} \\
0.2 \pm 0.2 \\
1.0 \pm 0.3 \\
8.0 \pm 1.7^{a} \\
0.4 \pm 0.1 \\
0.3 \pm 0.1^{b} \\
1.9 \\
5.3\end{array}$ & $\begin{array}{l}1.7 \pm 0.6^{b} \\
0.4 \pm 0.2 \\
1.9 \pm 0.5 \\
2.6 \pm 0.9^{b} \\
1.0 \pm 0.5 \\
0.3 \pm 0.2^{b} \\
0.7 \\
4.6\end{array}$ & $\begin{array}{l}1.0 \pm 0.3^{b} \\
0.3 \pm 0.1 \\
1.5 \pm 0.3 \\
0.2 \pm 0.1^{b} \\
1.5 \pm 0.5 \\
0.0^{b} \\
0.2 \\
1.7\end{array}$ \\
\hline Total & $28.9 \pm 5.5^{\mathrm{a}}$ & $18.9 \pm 1.8^{\mathrm{ab}}$ & $14.3 \pm 2.2^{b c}$ & $6.4 \pm 1.0^{c}$ \\
\hline $\begin{array}{l}\text { Shrubs and Trees } \\
\text { Barberis repens } \\
\text { Rubus strigosus } \\
\text { Pinus ponderosa } \\
\text { Quercus macrocarpa } \\
\text { Other spp. }\end{array}$ & $\begin{array}{l}0.0^{\star} \\
0.0 \\
4.5 \pm 0.9^{n} \\
13.2 \pm 5.4 \\
1.0\end{array}$ & $\begin{array}{l}3.5 \pm 1.3^{\mathrm{ab}} \\
2.8 \pm 1.7 \\
6.7 \pm 0.8^{\mathrm{ab}} \\
8.7 \pm 1.9 \\
2.0\end{array}$ & $\begin{array}{l}6.1 \pm 2.2^{b c} \\
1.6 \pm 2.0 \\
8.7 \pm 1.1^{b c} \\
12.2 \pm 3.0 \\
1.8\end{array}$ & $\begin{array}{c}9.7 \pm 2.3^{\mathrm{c}} \\
3.2 \pm 1.2 \\
9.4 \pm 1.0^{\mathrm{c}} \\
12.4 \pm 2.0 \\
2.3\end{array}$ \\
\hline Total & $18.7 \pm 5.9$ & $24.0 \pm 3.2$ & $30.6 \pm 4.2$ & $37.0 \pm 3.4$ \\
\hline
\end{tabular}

'Means for each plant (row) followed by the same letter superscript were not significantly different $(\alpha=0.10)$. Plants without superscripts were not different amont months ( $\alpha=$ $0.10)$. All values are relative density.

${ }_{2}^{2}$ Plants occurring at $1 \%$ or less in diets among all dates. Grasses and grasslikes: Bouteloua gracilis, Calamagrostis spp., Elymus villosus, Juncus spp., Koeleria cristata, Phleum pratensis; Forbs: Achillea millifolium, Astragalus spp., Eriogonum spp., Leguminosae family spp., Lesquerella spp., Lupinus pusillus, Melilotus officinalis, Valeriana spp.; Shrubs and Trees: Artemisia ludoviciana, Ceanothus spp., Juniperus spp., Prunus virginiana, Rhus glabra, Rosa spp., Sheperdia canadensis, Symphoricarpos spp., Populus tremuloides, Salix spp.

tance as the season progressed. A total of 48 plants were identified in the fecal material.

Plant composition on the study area was made up of 135 species. Grasses eaten by cattle in August made up $16 \%$ of the canopy cover, forbs $14 \%$, and shrubs-trees $20 \%$ (Table 2). Understory grasses, forbs, and shrub-trees eaten by cattle were relatively minor in canopy cover. Kentucky bluegrass and timber oatgrass had $6 \%$ and $5 \%$ canopy cover, respectively. Important forbs included white clover and miscellaneous legumes while shrubs included snowberry and Oregon grape.

Differences between plants found in the August diet and canopy cover were significant $(P<0.10)$ among 9 grass and grasslike species (Table 2). These included wheatgrasses, bentgrasses (Agrostis spp.), big bluestem (Andropogon gerardii), smooth brome (Bromus inermis), sedges, wildrye (Elymus villosus), green muhly (Muhlenbergia racemosa), Kentucky bluegrass, and needlegrasses. Cinquefoil (Potentilla spp.) a forb showed a greater portion in the diet than of the canopy cover $(P<0.10)$. The woody specieschokeberry, snowberry, ponderosa pine, and bur oak-also differed between proportion of the diet and canopy cover estimates $(P<0.10)$, indicating a significant selection or avoidance for a plant species.

When August cattle diets were compared with canopy cover of forage, similarities averaged $26 \%$ for grasses and $35 \%$ for shrubtree categories. Forbs had a $46 \%$ similarity. The overall similarity of cattle diet with forage abundance was $35 \%$. A high similarity indicates that the cattle are consuming plants in the same relative amounts that they are available. Low similarities indicate that cattle select plants for consumption. Spearman's rank order correlation coefficients were significant ( $P \leq 0.10)$ for grass and grasslike plants $(0.60)$ and for all plants $(0.31)$. However, forb $(0.49)$ and the shrub-tree categories $(0.11)$ were not significant. These lower rank order coefficients indicate that the rank order of plants in the diets was different than the rank order of forage species on the range. This also indicates that cattle sclect certain forage over others.

\section{Discussion}

Sedges, wheatgrasses, and timber oatgrass were major grass and grasslike species in cattle diets. These plants can be designated as key species for long-term range management practices such as grazing intensity and maintenance of forage plants. Kentucky bluegrass made up $4 \%$ of the diet, but was consumed in lesser amounts than available ( $6 \%$ canopy cover). This indicates that Kentucky bluegrass is not a highly preferred species when other forage plants are available.

Forbs were greatest in the cattle diets early in the season $(29 \%)$, then declined as the season progressed. This same trend has been reported by other investigators in Oregon (Holechek et al. 1982a, 1982b). As forbs decreased in the diet, shrub-tree use increased at the end of the grazing season to $37 \%$ of the total diet. Shrub use was greatest when grasses and forbs were mature and dying. Holechek ct al. (1982b) and Roath and Krueger (1982) obscrved a similar trend with browse making up $47 \%$ of the cattle diet when green grass was not available. Bur oak, snowberry, and Oregon grape 
Table 2. Auguat cattle diets (\%) and canopy cover (\%) by plant species in the northern Bhek Hills.

\begin{tabular}{|c|c|c|}
\hline Grasses and grasslikes & Diet $^{1}$ & Cover' \\
\hline $\begin{array}{l}\text { Category } \\
\text { Agropyron spp. } \\
\text { Agrostis spp. } \\
\text { Andropogon gerardii } \\
\text { Bromus inermis } \\
\text { Carex spp. } \\
\text { Danthonia intermedia } \\
\text { Elymus villosus } \\
\text { Juncus spp. } \\
\text { Koeleria cristata } \\
\text { Muhlenbergia racemosa } \\
\text { Oryzopsis spp. } \\
\text { Poa pratensis } \\
\text { Sorgastrum nutans } \\
\text { Stipa spp. }\end{array}$ & $\begin{array}{l}6.6 \\
1.8 \\
4.6 \\
4.6 \\
8.2 \\
9.0 \\
0.5 \\
0.1 \\
0.1 \\
4.4 \\
0.6 \\
5.0 \\
0.2 \\
7.1 \\
\end{array}$ & $\begin{array}{c}0.1^{*} \\
0.1^{*} \\
0^{*} \\
0.5^{*} \\
1.2^{*} \\
5.2 \\
.1^{*} \\
0 \\
0 \\
0^{*} \\
2.4^{*} \\
6.1^{*} \\
0 \\
0.1^{*}\end{array}$ \\
\hline Total & $\overline{52.8}$ & $\overline{15.8}$ \\
\hline $\begin{array}{l}\text { Forbs } \\
\text { Astragalus spp. } \\
\text { Composite } \\
\text { Erigeron spp. } \\
\text { Eriogonum spp. } \\
\text { Leguminosae spp. } \\
\text { Lupinus rusillus } \\
\text { Potentilla spp. } \\
\text { Trifolium repens } \\
\text { Verbascum thapsus } \\
\text { Vicia spp. } \\
\text { Unknown }\end{array}$ & $\begin{array}{l}0.2 \\
1.7 \\
0.4 \\
0.1 \\
0.8 \\
0.7 \\
1.9 \\
2.6 \\
1.0 \\
0.3 \\
-- \\
\end{array}$ & $\begin{array}{c}0.1 \\
2.6 \\
0.3 \\
0 \\
3.3 \\
2.6 \\
0.2^{*} \\
3.7 \\
0 \\
0.6 \\
\end{array}$ \\
\hline Total & 9.7 & $\overline{13.4}$ \\
\hline $\begin{array}{l}\text { Shrubs and Trees } \\
\text { Barberis repens } \\
\text { Prunus virginiana } \\
\text { Rhus glabra } \\
\text { Rosa spp. } \\
\text { Rubus strigosus } \\
\text { Shepherdia canadensis } \\
\text { Symphoricarpos spp. } \\
\text { Pinus ponderosa } \\
\text { Quercus macrocarpa } \\
\text { Salix spp. }\end{array}$ & $\begin{array}{r}6.1 \\
0.3 \\
0.2 \\
0.2 \\
1.6 \\
0.6 \\
0.2 \\
8.7 \\
12.2 \\
0.5 \\
\end{array}$ & $\begin{array}{c}4.7 \\
0.6^{*} \\
.1 \\
1.4 \\
.1 \\
1.7 \\
9.2^{*} \\
0.8^{*} \\
1.5^{*} \\
0 \\
\end{array}$ \\
\hline Total & 30.6 & 19.9 \\
\hline
\end{tabular}

* Diet different from cover at $P<0.10$. Unknowns not included.

'Pooled across sites. Diet values are relative density.

were the major shrub-tree species found in the cattle diets of this study.

This study indicates that cattle in the Black Hills do not consume plants in the same relative amounts as they occur on the range, which supports what Uresk and Rickard (1976) and Holechek et al. (1982a, 1982b) found. Knowledge of dietary selection and seasonal changes of forage species consumed can help managers improve grazing management practices. The data presented here on cattle diets, in combination with data on deer diets (Schneeweis et al. 1972), may help to improve allocation of forage, decrease competition between cattle and deer, and maintain maximum use of forage species with sustained yields.

\section{Literature Cited}

Boldt, Charles E., Robert R. Alexander, and Milo J. Larson. 1983. Interior ponderosa pine in the Black Hills. p. 80-83. In: Silvicultural Systems for the Major Forest Types of the United States. USDA Forest Service Handbook No. 445. Russell M. Burns. Technical Compiler. USDA Washington, D.C.

Bjugstad, Ardell J., and Arlo V. Dalyrmple. 1968. Beef heifers on Ozark ranges. Missouri Agr. Exp. Sta. B-870, Univ. of Missouri, Columbia.

Carmer, S.G., and M.R. Swanson. 1973. An evaluation of ten pairwise multiple comparison procedures by Monte Carlo methods. J. Amer. Stat. Ass. 68:66-74.

Daubenmire, R. 1959. A canopy-coverage method of vegetation analysis Northwest Sci. 33:43-64.

Dunnett, Charles W. 1980. Pairwise multiple comparisons in the unequal variance case. J. of Amer. Stat. Ass. 75:796-800.

Holechek, Jerry L., Martin Vavra, Jon Skovlin, and William C. Krueger. 1982a. Cattle diets in the Blue Mountains of Oregon I. Grasslands. J. Range Manage. 35:109-112.

Holechek, Jerry L., Martin Vavra, Jon Skovlin, and William C. Krueger. 1982b. Cattle diets in the Blue Mountains of Oregon Il. Forests. J. Range Manage. 35:239-242.

Nickerson, Mona F., Glen E. Brink, and Charles Feddema. 1976. Principal range plants of the central and southern Rocky Mountains: Names and symbols. USDA Forest Scrv. Gen. Tcch. Rep. RM-20, 121 p. Rocky Mt. Forest and Range Exp. Sta., Ft. Collins, Colo.

Nie, N.H., C.H. Hull, J.G. Jenkins, K. Steinbrennor, and D.H. Bent. 1975. SPSS: statistical package for the social sciences. 2nd ed. McGraw-Hill Pub. Inc., USA.

Oosting, H.J. 1956. The study of plant communities. W.H. Freeman and Co., San Francisco, Calif.

Pase, Charles P., and Richard M. Hurd. 1957. Understory vegetation as related to basal area, crown cover, and litter produced by immature ponderosa pine stands in the Black Hills. p. 156-158. Proc. Soc. of Amer. Forest., New York.

Pase, Charles P. 1958. Herbage productions and composition under immature ponderosa pine stands in the Black Hills. J. Range Manage. 11:238-243.

Payne, Gene F. 1974. Cover-weight relationships. J. Range Manage. 27:403-404.

Rogers, Lee E., and Daniel W. Uresk. 1974. Food plant selection by the migratory grasshopper (Melanoplus sanquinipes) within a cheatgrass community. Northwest Sci. 45:230-234.

Roath, Leonard Roy, and William C. Krueger. 1982. Cattle grazing influence on a mountain riparian zone. J. Range Manage. 35:100-103.

Schneeweis, James C., Kieth E. Severson, and Lyle E. Peterson. 1972. Food habits of deer in the Black Hills. Part I. Bull. 606. Agr. Exp. Sta., S. Dakota State Univ.

Severson, Kieth E., and Charles E. Boldt. 1977. Options for Black Hills forest owners: timber, forage, or both. Rangeman's Journal 4:13-15.

Siegel, S. 1956. Non-parametric statistics for behavioral sciences. McGraw-Hill Book Co., Inc., New York.

Senft, R.L., L.R. Rittenhouse, and R.G. Woodmansee. 1983. The use of regression models to predict spatial patterns of cattle behavior. J. Range Manage. 36:553-557.

Sparks, D.R., and J.C. Malechek. 1968. Estimating percentage dry weight in diets using a microscopic technique. J. Range Manage. 21:264-265.

Thilenius, John F. 1972. Classification of deer habitat in the ponderosa pine forest of the Black Hills. South Dakota. USDA Forest Service RM-91. Rocky Mtn. Forest \& Range Exp. Sta.. Forest Service, Ft. Collins, Colo.

Uresk, Daniel W., and W.H. Rickard. 1976. Diets of steers on a shrubsteppe rangeland in south-central Washington. J. Range Manage. 29:464-466. 